\title{
The duration of cost-cutting effects of price-lists
}

\author{
Ulf Martin Schilling \\ From Danish Society for Emergency Medicine: Research Symposium 2010 \\ Roskilde, Denmark. 20-21 May 2010
}

\section{Background}

In a recent study it was shown that price lists do have a positive impact on the cost-development at the emergency department. Earlier studies showed that the effect of price lists might decline during the following periode, however, no clear schedule for this process could be shown. In this study, we evaluated the declining performance of price lists distributed at a single time point in the context of the emergency department to find the optimum schedule for recurrent intervention.

\section{Methods}

Price lists including the most common laboratory and radiological investigations were created. The lists were distributed to all physicians on-call in internal medicin by email in april 2008. Further lists were exposed at the ED continually until September 2008. Mean costs for radiologic investigations for all medical and orthopaedic patients during the baseline months of june and july 2007 and from june 2008 till mars 2009, the percentage of radiological investigations for the respective line and the percentage of admission were calculated. Neither clinical nor admission procedures were changed during the period investigated. The physicians were unaware of the study. Statistical analysis was performed on a bimonthly base using the Student's T-test. Probability levels $<0.01$ were accepted as significant.

\section{Results}

A total of 1442 orthopaedic and 1585 medical patients were accounted during june and july 2007. Between june 2008 and mars 2009, 7987 orthopaedic and 9302 medical patients were attended. The radiological costs for medical patients started to climb 8 months after the intervention $(+16 \%)$ resulting in a significant increase at 10 months $(+48 \%, \mathrm{p}<0.001)$, whilst the radiological

Correspondence: mschillingdeu@netscape.net

Department of accidents and emergencies, Linköpings university hospital, Sweden costs for orthopaedic patients slightly increased at 8 months $(+13 \%, \mathrm{p}=0.1)$ to stabilize afterwards. Admission rates for medical patients did not differ significantly, whilst a decrease in admission rates for orthopaedic patients could be observed $(\mathrm{p}<0.01)$. No significant difference in the rate of radiological investigations could be found for each line.

\section{Conclusion}

Price lists are effective to reduce costs at the context of the emergency department. The effect of single interventions declined after 8 months. A repetition after a period of 6 to 8 months might be appropriate to conserve the cost-reducing effects.

Published: 17 September 2010

doi:10.1186/1757-7241-18-S1-P35

Cite this article as: Schilling: The duration of cost-cutting effects of price-lists. Scandinavian Journal of Trauma, Resuscitation and Emergency Medicine 2010 18(Suppl 1):P35.
Submit your next manuscript to BioMed Central and take full advantage of:

- Convenient online submission

- Thorough peer review

- No space constraints or color figure charges

- Immediate publication on acceptance

- Inclusion in PubMed, CAS, Scopus and Google Scholar

- Research which is freely available for redistribution

Submit your manuscript at www.biomedcentral.com/submit
C Biomed Central 